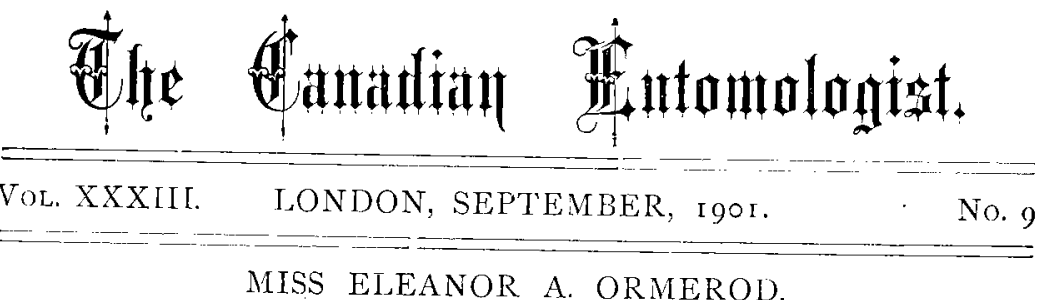

Entomology in England has suffered a great loss through the death of this talented and estimable lady, who died at her residence, Torrington House, St. Albans, on Friday, July 1 gth. Practical entomologists throughout the world are moved with profound regret that a career so remarkable and so useful should be brought to a close, but one could hardly hope that the aged lady would long be able to sustain the burden of increasing infirmities and the trials of a painful and protracted illness.

Miss Ormerod was born at Sedbury Park, Gloucestershire, on May I I th, 1828 , and had thus entered upon her 74 th year. She was the youngest of a family of ten, seven of them sons, all of whom sine survived. Her father, Mr. George Ormerod, LL. D., F. R. S., F. S. A., etc., was a distinguished literary man and the author of a rotable "History of Cheshire"; her mother was a daughter of Dr. John Latham, F. R. S., at one time President of the College of Physicians. On both sides, therefore, she inherited literary and scientific tastes, and at an early age displayed a love for natural history and outdoor pursuits. As her father became advanced in years, it devolved upon her to take a large share in the management of his estates, which included a home-farm, and in this way, no doubt, she was led to give the practical turn to her entomological investigations which caused them to be of so much public value afterwards. She also when quite young took an interest, that she continued to maintain throughout her life, in meteorological observations, and in course of time published "The Cobham Journals" of meteorological and phenological records made by Miss Molesworth at Cobham in Surrey. She was the first lady to be admitted as a Fellow of the Royal Meteorological Society, as she was also the first lady to receive (last year) the honorary degree of Doctor of Laws at the University of Edinburgh. Among other honours bestowed upon her may be mentioned the Silver Medals of the Société Nationale d'Acclimitation of France and the Royal 
Horticultural Society of England; the Gold Medal of Honour and two Silver Medals from the University of Noscow; and Honorary Membership in many Scientific Societies both in Europe and America.

Among her entomological publications may be mentioned the "Manual of Injurious Insects," I 881 ; "Guide to Methods of Insect Life," I884; "Injurious Insects of South Africa," r889; "A Text-book of Agricultural Entomology"; and the long series of "Annual Reports of Injurious Insects and Common Farm Pests," from 1878 to $190 \mathrm{I}$. The last of these Reports, the twenty-fourth volume, we noticed in the May number of this magazine, and gave some account of their great practical value and the wide range that they cover.

Miss Ormerod was one of the most remarkable women of the latter half of the nineteenth century, and did more than any one else in the British Isles to further the interests of farmers, fruit-growers and gardeners, by making known to them methods for controlling and subduing their multiform insect pests. Her labours were unwearied and unselfish; she received no remuneration for her services, but cheerfully expended what means she possessed in carrying out her investigations and publishing their results. We know not now by whom in England this work can be continued; it is not likely that any one can follow in the unique path laid out by Miss Ormerod; we may therefore cherish the hope that the Government of the day will hold out a helping hand and establish an entomological bureau for the lasting benefit of the great agricultural interests of the country.

C. J. S. B.

\section{ON TYPES OF ACRONYCTA, ETC.}

BY A. RADCliffe Grote, A. M., hildeshejm, Germany.

The following comments upon Prof. Smith's paper in Can. ENT. for Nov., I900, 33j, have suggested themselves to me. The types of Acronycta there discussed are the specimens in Brit. Mus. Coll., and in several instances my determinations are now adopted by the author.

A. pallidicoma, Grote.

This name is cited without comment, except that the type is a small female (334). It would have been more to the point if this name had been identified with one of the "two series into which xyliniformis allows itself to be so prettily divided" (Sm. and Dyar, p. I49). Whether as applied to a form or a species, the name is valid. It is not xyliniformis as 